Araştırma Makalesi / Research Article

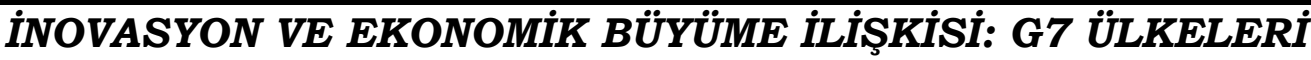
ÜZERINE PANEL VERI ANALIZZI

\section{İbrahim ÇÜTCÜ2}

\author{
Turgay BOZAN3
}

$\ddot{0} z$

İnovasyon, yeni veya önemli derecede iyileştirilmiş ürün ve süreçlerin geliştirilmesi olarak tanımlanmaktadır. Dolayısıyla bir ülkedeki inovatif gelişmeler ekonomik büyümeyi de etkilemektedir. Çalışmada inovasyon ile ekonomik büyüme arasındaki ilişki, G-7 ülkeleri üzerinden incelenmektedir. Çalışmanin temel hipotezi, inovasyon ile ekonomik büyüme arasındaki ilişki vardır şeklinde belirlenmiştir. İnovasyon göstergesi olarak ar-ge harcamalar ve patent başvurular alınmıştır ve 1981-2016 dönemlerini kapsayan yıllık veriler ile panel veri analizi gerçekleştirilmiştir. Gerçekleştirilen analizler sonucunda, inovasyon ile ekonomik büyüme arasında uzun dönemli ilişki olduğu sonucuna ulaşılmıştır. Ekonomik büyüme ile ArGe arasında ise negatif yönlü ilişki tespit edilmiştir. Ayrica büyüme oranından patent başvurularına doğru ise tek yönlü nedensellik ilişkisi görülmüştür.

Anahtar Kelimeler: İnovasyon, Ekonomik Büyüme, Patent, Ar-Ge, G7 Ülkeleri

THE RELATIONSHIP BETWEEN INNOVATION AND ECONOMIC GROWTH: PANEL DATA ANALYSIS ON G7 COUNTRIES

\begin{abstract}
Innovation is defined as the development of new or significantly improved product or processes. Therefore, innovative developments in a country also affect economic growth. In this study, the relationship between the innovation and the economic growth is examined through $G 7$ countries. The main hypothesis of the study is that there is a relationship between innovation and economic growth. As an indicator of innovation, $R \& D$ expenditures and patent applications were taken and panel data analysis were performed with annual data covering 1981-2016 periods. As a result of the analyses, it was concluded that there is a long-term relationship between innovation and economic growth. A negative relationship was found between economic growth and $R \& D$. In addition, one-way causality relationship was observed from the growth rate to patent applications.
\end{abstract}

Keywords: Innovation, Economic Growth, Patent, R\&D, G7 Countries

\footnotetext{
${ }^{1}$ Bu çalışma, yazarlardan Turgay Bozan'in Hasan Kalyoncu Üniversitesi Sosyal Bilimler Enstitüsü İktisat Ana Bilim Dalında yürüttügü "İnovasyon ve Ekonomik Büyüme İlişkisi: G7 Ülkeleri Üzerine Ekonometrik Bir Analiz" başlıklı yüksek lisans tez çalışmasından türetilmiştir.

2 Doç. Dr., Hasan Kalyoncu Üniversitesi, İktisadi, İdari ve Sosyal Bilimler Fakültesi, İktisat Bölümü, ibrahim.cutcu@hku.edu.tr, orcid.org/0000-0002-8655-1553

3 Yüksek Lisans Öğrencisi, Hasan Kalyoncu Üniversitesi, Sosyal Bilimler Enstitüsü, İktisat Ana Bilim Dall, turgay.bozan@hku.edu.tr, orcid.org/0000-0001-7120-8712
} 


\section{Giriş}

Ülkelerin ekonomik büyüme performansları birçok faktörden etkilenmekte olup bu faktörlerin neler olduğu ve etki oranlarını belirlemeye yönelik birçok araştırma yapılmıştır. Bu araştırmaların vardığı ortak nokta, büyüme ve kalkınma performansında temel itici gücün teknoloji ve inovasyon olduğudur (OECD, 2007: 3). Sanayi Devrimi'nden bu yana inovasyonun ekonomik büyüme üzerindeki önemli etkisi herkes tarafından kabul edilmiş ve araştırmalar bu husus üzerine yoğunlaşmıştır. Literatürde, inovasyon performansının üretkenlik, karlılık ve büyüme gibi değişkenler ile ilişkileri birçok araştırmada incelenmiştir. Akademik çalışmaların bir kısmı işletme seviyesine odaklanırken, daha büyük resme odaklanan ve ülke seviyesinde hatta ülkeler arası seviyede analizler yapan çalışmalar da mevcuttur (Cameron, 1996: 10).

İnovasyon en basit şekilde yeni veya önemli derecede iyileştirilmiş ürün ve süreçlerin geliştirilmesi olarak tanımlanmaktadır. Ancak inovasyon riski de beraberinde getiren zor bir süreçtir. Bu süreçte amaçlanan hedefe ulaşmak planlanandan daha masraflı ve daha uzun sürebilir. Diğer taraftan rakipler tarafından pazara sunulan yenilikler daha iyi performans gösterdiği takdirde yenilikten beklenen gelir elde edilemeyebilir. İşletmeler veya daha büyük ölçekte ülkeler için inovasyonun getirdiği bu belirsizlikten kaçma şansı yoktur.

Ulusal düzeyde inovasyon aktivitelerinin ölçülmesi kolay bir işlem değildir. Çünkü kusursuz bir inovasyon ölçüm metodu bulunmamaktadır. İnovasyon performansı genellikle Ar-Ge ve patent verileri kullanılarak ölçülmektedir. Bu amaçla da genellikle Ar-Ge harcamaları, daha spesifik olarak Ar-Ge harcamalarının Gayri Safi Yurtiçi Hasıla (GSYH)'ya oranı ve patent istatistikleri kullanılmaktadır (Wang, 2013: 1). Bu yaklassımda Ar-Ge harcamaları girdi, patent istatistikleri de çıktı gibi düşünülebilir.

Küreselleşme ve dijitalleşmenin beraberinde getirdiği artan rekabet, ulaşılan bilgi yoğunluğu, sürekli olarak değişen ihtiyaçlar yenilik ve Ar-Ge kavramlarını işletmelerin ve ülkelerin üzerinde durduğu en önemli kavramlar haline getirmiştir. Yenilik, yeni fikirlerin çıkarılması ve ticarileştirilmesi süreçlerini içermektedir. Yenilik kavramını, icat kavramından ayıran en önemli özellik yeniliğin ticarileştirilmesidir. Farklı bir ifade ile "Yenilik=İcat+Ticarileştirme" olarak tanımlanabilir.

Yeniliğin ekonomik büyümenin itici gücü olduğu vurgusu yapmamalarına rağmen, Adam Smith, David Ricardo ve Karl Marx yeniliği tarihsel açıdan ele alan ilk iktisatçılar olarak ön plana çıkmaktadır (Kantarc1, 2017: 41). Karl Marx'ın eserlerinden ve fikirlerinden etkilenen Schumpeter "yaratıcı yıkım" olarak tanımladığ1 "sistemin hiç durmadan sürekli bir yenilenme içinde olduğunu ve sürekli olarak eski faktörleri yıkıp yenilerini yarattı̆̆ını" vurgulama sureti ile yeniliğin büyümenin itici gücü olduğunu ifade eden ilk ekonomisttir.

$\mathrm{Bu}$ bağlamda, gelişmiş ülkelerin yenilik faaliyetlerini yoğun olarak sürdürdükleri, bu kapsamda gerekli altyapı ve Ar-Ge faaliyetlerine yoğunluk verdikleri görülmektedir. Özellikle 1990'lı yıllardan sonra bilgiye yapılan yatırım makine ve ekipmana yapılan yatırımdan daha fazla artış göstermiş, hatta Finlandiya ve Amerika gibi ülkeleri de geride bırakmıştır (OECD, 2007: 6).

Ar-Ge harcamalarının GSYH içindeki payına bakıldığında gelişmiş ülkelerde bu oranın gelişmekte olan ülkelere nazaran daha yüksek olduğu görülmektedir (Ballı ve Güreşçi, 2017: 105). Bu bilgiler yapilan Ar-Ge harcamalarının büyüme üzerinde pozitif yönde önemli bir etkisi olduğunu 
göstermesi açısından son derece önemlidir. OECD tarafından 2007 yılında hazırlanan raporda, özellikle gelissmekte olan OECD ülkelerinde Ar-Ge harcama oranının arttığı belirtilmiştir. Bu kapsamda çalışmada, "İnovasyon ile ekonomik büyüme arasında uzun dönemli ilişki vardır." sseklinde kurgulanan hipotez G7 ülkeleri üzerinden analiz edilmektedir. Araştırmanın temel problemi "G7 ülkelerinde inovasyonun ekonomik büyüme üzerindeki etkisinin yaratmış olduğu küresel rekabet" olarak belirlenmiştir.

Dünyanın en önemli ekonomilerini oluşturan G7 ülkelerinde yenilik için gerekli altyapıyı oluşturan Ar-Ge faaliyetleri hem özel sektör hem kamu sektörü açısından oldukça yüksek düzeydedir. Günümüz küreselleşen rekabet ortamında gelişmekte olan ülkeler tarafından da yenilik performansını artırmaya yönelik yeni politikalar geliştirildiği görülmektedir. Bu kapsamda, gelişmekte olan ülkelerin de mevcut ekonomik sorunlarına çözüm bulabilmek adına yeniliğe ve yenilik için gerekli olan altyapı ve Ar-Ge faaliyetlerine daha fazla önem vermeleri gerektiği değerlendirilmektedir. Bu kapsamda, çalışmanın temel amacı yeniliğin G7 ülkelerinin ekonomik büyüme performansı üzerindeki etkisini değerlendirmektir. Yeniliğin ekonomik büyüme üzerinde etkilerinin G7 ülkeleri özelinde araştırılması, sadece gelişmiş ülkeler için değil, gelişmekte olan ülkeler için de önem arz ettiği bilinmektedir.

Belirtilen amaç çerçevesinde çalışmanın başlangıcında, inovasyon ve ekonomik büyüme kavramları açıklanmaktadır. Devamına ise G7 ülkeleri üzerinde inovasyon ve büyüme rakamlarının değerlendirilmesi yapılarak teorik ve kavramsal açıdan yorumlar getirilmiştir. Araştırmanın analiz kısmından önce ise belirlenen hipoteze yönelik literatür çalışması gerçekleştirilmiştir. Çalışmanın son bölümünde ise literatür de inovasyon ve ekonomik büyümeye yönelik ampirik ve teorik çalışmalar ışığında ekonometrik model kurgulanarak hipotez testleri gerçekleştirilmiştir. Yöntem olarak panel veri analizi testlerinin gerçekleştirildiği araştırmada elde edilen bulgular üzerinden politika önermeleri yapıldıktan sonra literatür ile karşılaştırması gerçekleştirilmiştir.

\section{2. İnovasyon-Ekonomik Büyüme İlişkisi}

İnovasyon ile ilgili literatür incelendiğinde, farklı yazarlar tarafından farklı tanımlamalar yapılmasına rağmen bu tanımların her birinin ortak noktada buluştuğunu belirtmek yanlış olmayacaktır. Örneğin, Keith ve Theodore (1984) inovasyonu bir süreç olarak tanımlamaktadır. Yazarlara göre inovatif süreç buluş ile başlar, ortaya konulan buluşun geliştirilmesi devam ederek piyasaya nihai ürün olarak girmesi ile sonuçlanır. Diğer taraftan, yeniliği teknik bir kavram olmaktan öte ekonomik ve sosyal bir kavram olarak nitelendiren Drucker (1985:30)'a göre ise yenilik "kaynaklara zenginlik kazandırmak için yeni bir kapasite yaratma eylemi" sseklinde tanımlamaktadır. Tushman ve Nadler (1986:75)'e göre yenilik "yeni bir ürünün, işlemin ya da hizmetin yaratılma sürecini” ifade etmektedir. Kavram Luecke tarafından ise "özgün ve yeni bir ürün, süreç ya da hizmet yaratmak için bilginin sentezi, kombinasyonu veya somutlaştırılması" olarak tanımlanmıştır (Luecke, 2011:3). Teknolojik yeniliğe odaklanan Betz (2013:23) inovasyon sürecini, teknolojik ürünün bulunması, piyasaya aktarılan yüksek teknolojili ürün, hizmet ve işlem olarak görmektedir. Örtlek (2015) tarafından inovasyon geniş bir süreci kapsamaktadır. Bu süreç fikrin ortaya çıkarılmasından toplumsal fayda sağlamasına, değer yaratan ürün haline gelmesine ve iş yapış yöntemlerine dönüştürülmesine kadar geçen bir süreçtir. 


\section{İbrahim ÇÜTÇÜ \& Turgay BOZAN}

Teknolojik inovasyon ise ekonomik büyümenin en önemli kaynaklarından birisidir. Bu kapsamda, işletmelerin ve ülkelerin yenilik çabalarına yatırım yapması gerekmektedir. İnovasyon teknolojik değişim sürecini tetiklemek sureti ile refah artış1 ve kalkınma üzerinde kritik öneme sahiptir (Kavak, 2009: 619). Teknolojik yeniliğin ekonomik büyüme konusundaki önemine değinen ilk araştırmacı olan Schumpter'in yaklaşımına göre yenilik ekonomik gelişmenin ve ekonomideki dalgalanmaların ana unsurudur.

Ekonomik büyüme ile ilgili literatür incelendiğinde inovasyon Ar-Ge harcamaları, patent sayısı veya inovasyon sayısı gibi değişkenlerden hangileri ile ölçülürse ölçülsün hem işletme hem de endüstri ve ülke seviyesinde büyüme üzerinde önemli etkisi olduğu sonucuna ulaş1mıştır (Cameron, 1996: 5). Son dönemde ortaya atılan büyüme teorileri de ekonomik büyüme üzerinde teknolojik değişimin ve yeniliğin önemine vurgu yapmaktadır (Geroski, vd., 1993: 198). İnovasyonun ekonomik büyüme üzerindeki etkisini inceleyen araştırmalarda kullanılan bazı temel inovasyon göstergeleri şu şekildedir (Karaöz ve Albeni, 2004:4);

- Ekonomide belirli dönemlerde yapılan yenilik miktarı,

- Patentler, patent başvuruları,

- Bilimsel yayınlar,

- Ar-Ge harcamalar1,

- Araştırmacı sayıları.

Ülkelerin rekabet güçleri, ekonomik potansiyellerini etkilemektedir. Rekabet gücünü artıran en önemli unsur ise ülkede bulunan işletmeler tarafından yapılan yeniliklerdir. Bu nedenle inovasyon, ülkeler için ekonomik büyümenin, istihdam artışının ve yaşam kalitesinin yükselmesinin en önemli etkeni durumundadır (Elçi, 2007: 31). İnovasyon, makro ölçekte ülkelerin mikro ölçekte ise firmaların uluslararası rekabet gücünü belirlemede, refah ve yaşam kalitesinin arttırılmasında temel bir unsurdur (Işık ve Kılınç, 2011:14). Bu bağlamda inovasyon, küresel dünyada iktisadi büyümeden yaşam standartlarının geliştirilmesine kadar geçen birçok süreçte ülkelerin vazgeçilmez aracı haline gelmiştir (Y1lmaz ve İncekaş, 2018).

\section{G7 Ülkeleri ve Ekonomik Yapıs1}

Dünyanın ekonomik açıdan en zengin ülkelerinin, global ölçekte ekonomik ve parasal sorunları görüşmek ve bu konularda iş birliği yapmak amacıyla oluşturdukları grubun adı öncelikle G6 olarak belirlenmiștir. Grup üyesi kurucu ülkeler ABD, Japonya, Almanya, İngiltere, Fransa ve İtalya'dır. İlk kez 1975 yılında toplanan gruba 1976 yılında Kanada'nın katılması ile G7, 1997 yılında Rusya'nın katılması ile G8 adını almıştır. Ancak 2015 yılında Kırım'ı işgal ettiği gerekçesi ile Rusya Devlet Başkanı Vladimir Putin 2016 yılındaki zirveye davet edilmeyince grubun üye ülke sayısı tekrar 7'ye inmiştir. Çalışmada, inovasyon ile ekonomik büyüme arasındaki ilişki G-7 ülkeleri üzerinden analiz edilmektedir.

Shiller (2012: 13)'e göre yeniliğin önündeki en büyük engel yeni ve bilinmeyen bir șeye yatırım yapma cesaretinin bulunmamasıdır. Yazar bu engelin devlet destekleri ile aş1labileceğini savunmuştur. G7 Ülkelerinde de Ar-Ge harcamalarının bir kısmı devlet tarafından yapıldığı gibi, özel sektör tarafından yapılan Ar-Ge yatırımları da proje kapsamında verilen hibe ve düşük faizli krediler veya vergi indirimleri ile tessvik edilmektedir. 
Uluslararas1 Para Fonu (International Monetary Fund-IMF) verilerine göre G7 ülkelerinin ortalama büyüme oranı Şekil 1'de verilmiştir.

Şekil 1: G7 Ülkelerinin Ortalama Ekonomik Büyüme Oranları

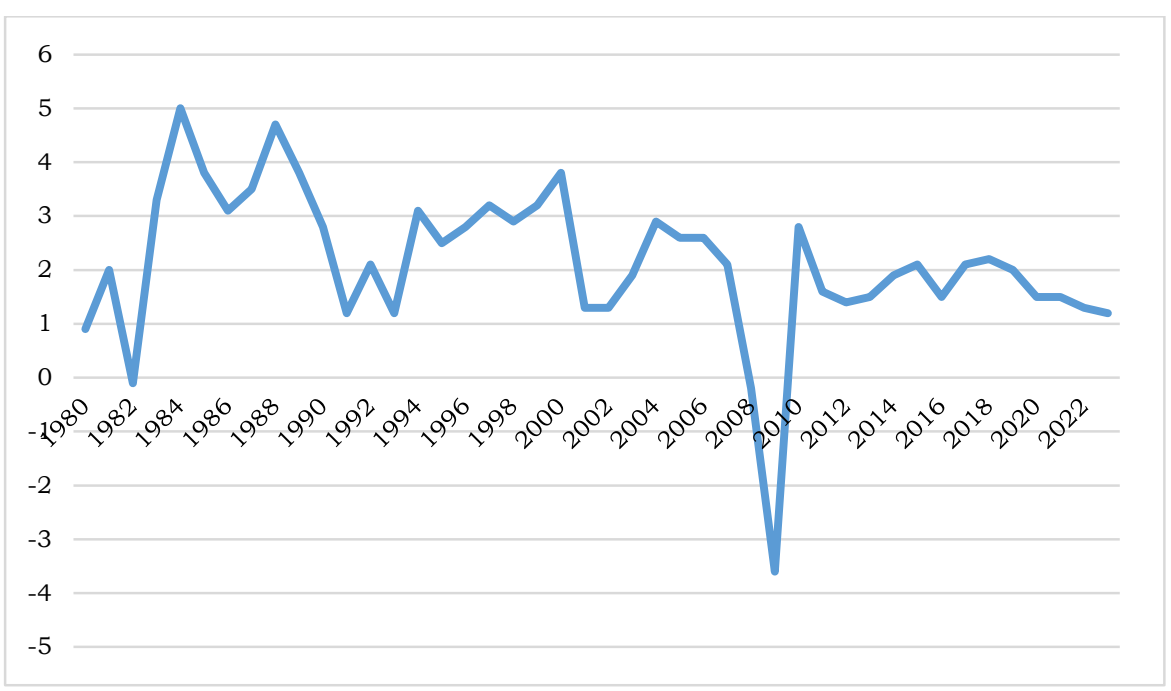

Kaynak: IMF veri tabanından düzenlenmiştir.

Şekil 1'de görüleceği üzere G7 ülkelerinin 2000'li yıllarda büyüme oranlar1 1980'li ve 1990'l1 y1llardaki seviyelerinden daha düşük gerçekleşmektedir. Özellikle 2008 yılında yaşanılan küresel krizin etkilerinin dip yarattığı büyüme verilerinde 2010 yılı itibariyle toparlanmanın yaşandığ görülmektedir. Ayrıca 2000'li yıllara kadar dalgalı ve istikrarsız bir seyir izleyen G7 ülkelerinin 2010 itibariyle biraz daha istikrarlı ve \%2 bandında olduğu söylenebilir.

Şekil 2: G7 Ülkelerinin Küresel GSYH İçerisindeki Payları

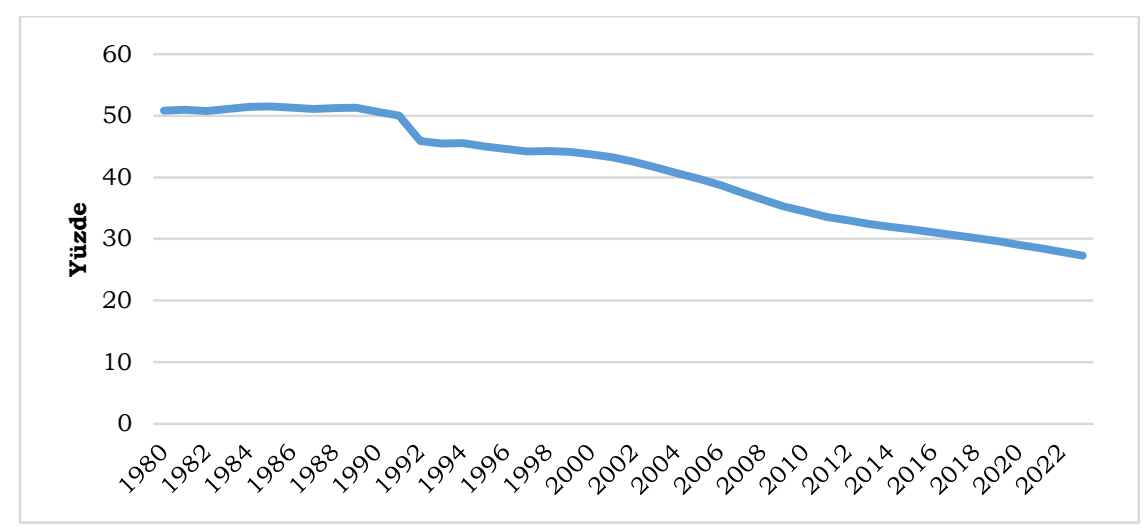

Kaynak: IMF veri tabanından düzenlenmiştir.

G7 ülkeleri küresel ekonomide önemli bir aktördür. Şekil 2'de görüleceği üzere 1980'li yıllara kadar küresel ekonominin yarısına yakın hâkimiyeti olan bu ülkelerde zamanla zayıflama görülmüss olup küresel GSYİH içindeki payı 
azalmıştır. 2019 y1lı itibariyle \%30'unda altına düşen G7 ülkeleri, yeni rekabetçi sistemde ar-ge ve inovasyon odaklı politikalara ağırlık vermesi kaçınılmaz hale gelmiştir.

G7 ülkeleri birçok sosyo-ekonomik faktörde olduğu gibi inovatif faaliyetlerde de dünya sıralamasında üst sıralardadır. Çalışmada inovasyon göstergesi olarak literatür ile uyumlu bir şekilde ar-ge harcamaları ile patent başvuruları alınmıștır. $\mathrm{Bu}$ iki gösterge dikkate alındığında birçok dünya ülkesinden daha başarılı oldukları söylenebilir. Fakat kendi aralarında yapılan karşılaştırmalarda ise patent başvuruları dikkate alındığında ABD ve Japonya'nın daha başarılı olduğu söylenebilir. Fakat ar-ge harcamalarına göre yapılan karşılaştırmada ise ülkeler arasında ciddi farklılıkların olmadığı görülmektedir.

Şekil 3: G7 Ülkelerinde Toplam Patent Başvuru Sayıları

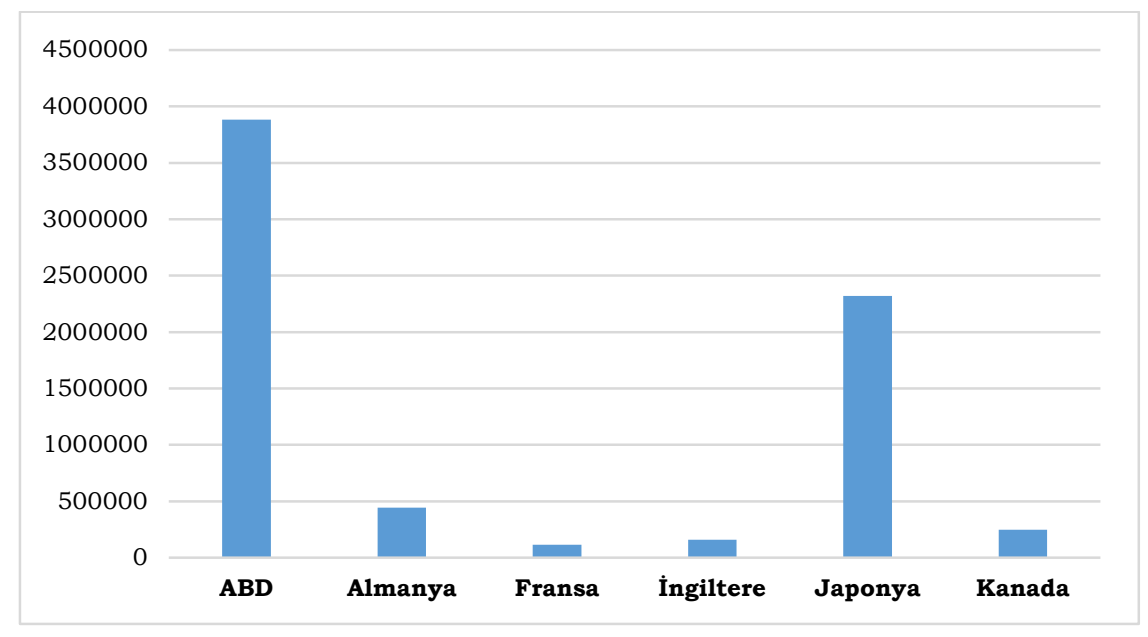

Kaynak: OECD, 2018

Şekil 4: G7 Ülkelerinde Toplam Ar-Ge Harcamaları/GSYIH

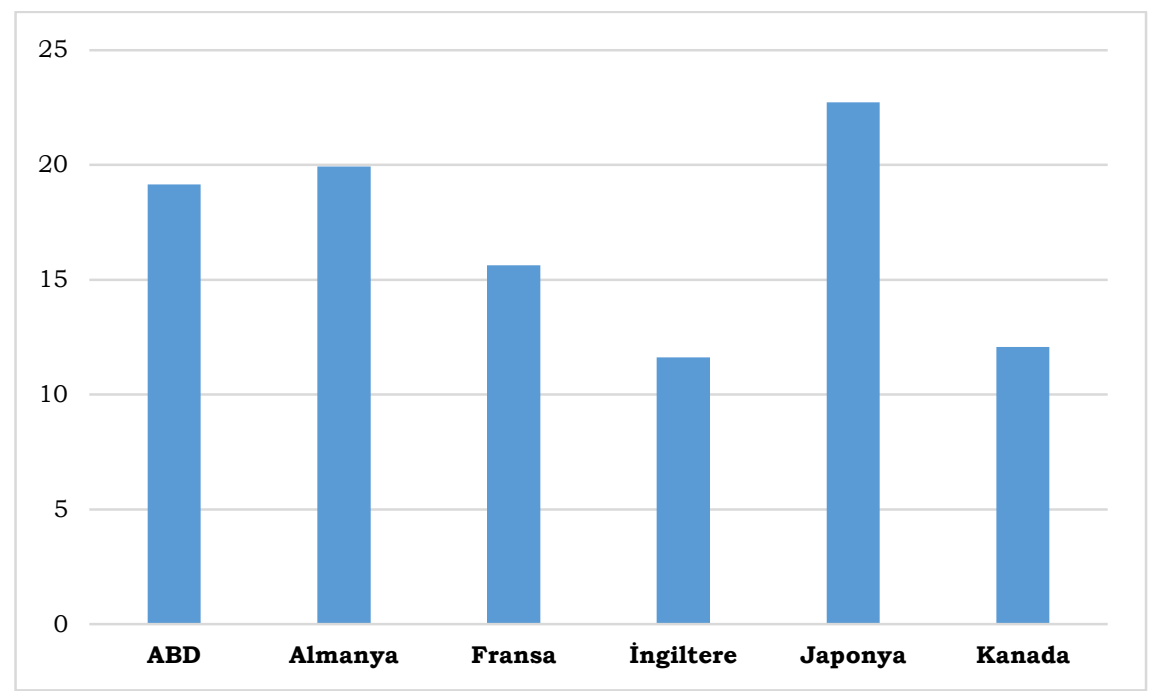

Kaynak: OECD, 2018 
Ar-Ge harcamalarının milli gelire oranı incelendiğinde ise G7 ülkeleri arasında Ar-Ge ve yenilik faaliyetlerine en büyük yatırımın Japonya tarafından, en düşük yatırımın ise Kanada ve İngiltere tarafından yapıldığı görülmektedir. G7 ülkeleri ortalama olarak milli gelirden alınan payın \%2,25 ini Ar-Ge faaliyetlerine harcamaktadır ki bu dünya ortalamasının üzerinde bir orandır. Bunun, gelişmekte olan ülkeler tarafından Ar-Ge faaliyetlerinin öneminin ve ekonomik büyüme üzerindeki etkisinin anlaşılabilmesi açısından önemli bir bulgu olduğu değerlendirilmektedir. Ar-Ge harcamalarının milli gelire oranı konusunda lider olan Japonya, patent başvurularında ABD ile birlikte yine zirvededir. G7 ülkeleri arasında en az patent başvurusuna sahip ülkeler ise Fransa ve İngiltere'dir.

\section{Literatür Araştırması}

İnovasyon, Schumpeter tarafından ekonomik büyümenin bir kaynağı olarak görülmektedir (Brouwer, 2000: 149-150). Teknolojinin ve teknolojik inovasyonun ekonomik büyüme üzerindeki etkisi ilk olarak Neo-Klasik gelenekte Solow'un büyüme teorisinde yer almıştır. Ancak araştırmalarda, teknolojinin nasıl üretildiğine dair açıklamalar yeterli düzeyde getirilememiştir. Bu yetersizliği, nedeni ile Neo-Klasik büyüme teorisi yerini içsel büyüme teorisine bırakmıştır. Romer (1986), Barro (1991), Grossman ve Helpman (1991), Aighon ve Howitt (1992) gibi iktisatçıların öncülüğünde gelişen içsel büyüme teorilerinde teknoloji ekonomik sistemin içerisinde belirlenmektedir. Örneğin, Romer (1990)'a göre ArGe faaliyetleri sonucu ortaya çıkan teknolojik inovasyonlar ekonomik büyümenin motoru durumundadır (Gülmez ve Akpolat, 2014: 4).

Son dönemde, inovasyon ile ekonomik büyüme ilişkisi akademik çalışmalara sıkça konu olmaktadır. Bahse konu çalışmalarda inovasyon genellikle Ar-Ge harcamaları ve patentler ile ölçülmektedir (Özkul ve Örün, 2016: 18). Örneğin, Lichtenberg (1992) 74 ülkenin özel ve kamu Ar-Ge yatırımları ile ekonomik büyüme arasındaki ilişkiyi incelemiş ve özel sektör tarafından yapılan Ar-Ge yatırımları ile ekonomik büyüme arasında anlamlı bir ilişki olduğu sonucuna ulaşmıştır. Benzer şekilde Cameron (1998) inovasyonun ekonomik büyümeye önemli bir katkı yaptığ1 sonucuna ulaşmıştır. Sylwester (2001) tarafından yapılan araştırma sonucunda ise ilginç bulgulara ulaşılmıştır. 20 OECD ülkesinin verileri kullanilarak yapilan inceleme sonucunda Ar-Ge harcamaları ile büyüme arasında herhangi bir ilişki olmadığı, ancak G7 ülkelerinin verileri kullanılarak yapılan incelemede ise iki değişken arasında güçlü bir ilişki olduğu sonucuna ulaş1lmıştır. Audretsch vd. (2008) tarafından Almanya'da yapılan çalışmada da, inovasyon çabalarının ekonomik performans üzerinde dolaylı bir etkiye sahip olduğu sonucuna ulaşılmıştır. Diğer taraftan, Hasan ve Tucci (2010) tarafından 58 ülkenin verisi kullanılarak yapılan çalışma sonucunda patent niteliklerinin ekonomik büyümeyi önemli derecede etkilediği anlaşılmıştır. Zhang vd. (2012) tarafından Pekin'de yapılan çalışmada inovasyon ile ekonomik büyüme arasında uzun dönemli bir ilişki olduğu, Galindo ve Mendez (2013) tarafindan 10 gelişmiş ülke verisi kullanılarak yapılan çalışmada ise inovasyonun ekonomik büyümeyi olumlu etkilediği sonucuna ulaşılmıştır.

Ekonomik büyüme ile yenilik, Ar-Ge harcamaları, patent sayısı gibi değişkenler arasındaki ilişkiye yönelik literatür araştırası ise Tablo 1'de detaylı olarak verilmiştir. 
İbrahim ÇÜTÇÜ \& Turgay BOZAN

Tablo 1: Literatür Araştırması

\begin{tabular}{|c|c|c|c|c|}
\hline Çalışma & Y11 & Ülke Sayısı & Değişkenler & Bulgular \\
\hline $\begin{array}{l}\text { Lichtenberg } \\
\text { (1993) }\end{array}$ & $\begin{array}{l}1964- \\
1989\end{array}$ & 74 ülke & $\begin{array}{l}\text { - Ar-Ge } \\
\text { harcamaları } \\
\text { - Verimlilik } \\
\text { - Ekonomik } \\
\text { büyüme }\end{array}$ & $\begin{array}{lr}\text { Özel sektör tarafından } \\
\text { yapılan } & \text { Ar-Ge } \\
\text { harcamaları ve ekonomik } \\
\text { büyüme arasında anlamlı } \\
\text { bir ilişki olduğu } \\
\text { saptanmiştır. }\end{array}$ \\
\hline $\begin{array}{l}\text { Freire-Serén } \\
\text { (1999) }\end{array}$ & $\begin{array}{l}1965- \\
1990\end{array}$ & 24 Ülke & $\begin{array}{l}-\quad \text { Ar-Ge } \\
\text { Harcamaları } \\
\text { - Ekonomik } \\
\text { Büyüme }\end{array}$ & $\begin{array}{l}\text { Ar-Ge harcamaları ile } \\
\text { ekonomik büyüme } \\
\text { arasında çok güçlü bir } \\
\text { ekonomik ilişki olduğu } \\
\text { saptanmıştır. }\end{array}$ \\
\hline Sylwester (2001) & $\begin{array}{l}1981- \\
1996\end{array}$ & $\begin{array}{l}16 \text { OECD } \\
\text { Ülkesi }\end{array}$ & $\begin{array}{l}\text { - Ar-Ge Harc. } \\
\text { - Ekon. } \\
\text { Büyüme }\end{array}$ & $\begin{array}{lrr}\text { Ar-Ge ile } & \text { ekon. } & \text { büyüme } \\
\text { arasında } & \text { bir } & \text { ilişki } \\
\text { olmadığ } 1 & \text { sonucuna } \\
\text { ulaşmıştır. } & \end{array}$ \\
\hline $\begin{array}{l}\text { Yanyun ve } \\
\text { Mingquian } \\
(2004)\end{array}$ & $\begin{array}{l}1994- \\
2003\end{array}$ & 8 Asya Ülkesi & $\begin{array}{l}\text { - Ar-Ge Harc. } \\
\text { - Ekon. } \\
\text { Büyüme }\end{array}$ & $\begin{array}{l}\text { Ar-Ge harç. ekonomik } \\
\text { büyüme üzerinde pozitif } \\
\text { yönde etkisi olduğu } \\
\text { sonucuna ulaşılmıştır. }\end{array}$ \\
\hline Wang (2007) & $\begin{array}{l}1991- \\
2006\end{array}$ & $\begin{array}{l}30 \text { Ülke (23 } \\
\text { OECD ülkesi, } \\
7 \text { OECD Üyesi } \\
\text { olmayan) }\end{array}$ & $\begin{array}{l}\text { - Ar-Ge Harc. } \\
\text { - Ekon. } \\
\text { Büyüme }\end{array}$ & $\begin{array}{lll}\text { Ar-Ge } & \text { harç. } & \text { Ekon. } \\
\text { büyüme üzerinde pozitif } & \text { pön } \\
\text { etkisi } & & \text { olduğu } \\
\text { görülmüştür. } & \end{array}$ \\
\hline $\begin{array}{l}\text { Goel ve Ram } \\
\text { (2008) }\end{array}$ & $\begin{array}{l}1960- \\
1980\end{array}$ & $\begin{array}{l}52 \text { ülke }(18 \\
\text { Gelişmiş, } 34 \\
\text { Gelişmekte } \\
\text { olan) }\end{array}$ & $\begin{array}{l}\text { - Ar-Ge Harc. } \\
\text { - Ekon. } \\
\text { Büyüme }\end{array}$ & $\begin{array}{l}\text { Analiz sonucunda Ar-Ge } \\
\text { harç. ile ekon. büyüme } \\
\text { arasinda uzun dönemli } \\
\text { bir ilişki } \\
\text { saptanmiştır }\end{array}$ \\
\hline Alene (2010) & $\begin{array}{l}1970- \\
2004\end{array}$ & $\begin{array}{l}52 \text { Afrika } \\
\text { ülkesi }\end{array}$ & $\begin{array}{l}\text { - Ar-Ge Harc. } \\
\text { - Ekon. } \\
\text { Büyüme }\end{array}$ & $\begin{array}{l}\text { Ar-Ge harç. büyüme } \\
\text { üzerinde pozitif ve } \\
\text { anlamlı bir etkisi olduğu } \\
\text { sonucuna ulaşılmıştır. }\end{array}$ \\
\hline Pece vd. (2015) & $\begin{array}{l}2000- \\
2013\end{array}$ & $\begin{array}{l}\text { Polonya, } \\
\text { Çekya, } \\
\text { Macaristan }\end{array}$ & $\begin{array}{l}\text { - Yenilik } \\
\text { • Ekon. } \\
\text { Büyüme }\end{array}$ & $\begin{array}{l}\text { Ekon. büyüme ve yenilik } \\
\text { arasında pozitif bir } \\
\text { ilişkinin var olduğu } \\
\text { saptanmiştır. }\end{array}$ \\
\hline $\begin{array}{l}\text { Bujari ve } \\
\text { Martinez (2016) }\end{array}$ & $\begin{array}{l}1996- \\
2008\end{array}$ & $\begin{array}{l}12 \text { Latin } \\
\text { Amerika } \\
\text { Ülkesi }\end{array}$ & $\begin{array}{l}\text { - Yenilik } \\
\text { - Ekonomik } \\
\text { Büyüme }\end{array}$ & $\begin{array}{l}\text { Latin Amerika } \\
\text { ülkelerinde teknolojik } \\
\text { yeniliğin } \\
\text { büyüme üzerinde pozitif } \\
\text { yönde etkisi olduğu } \\
\text { sonucuna ulaşmıştır. }\end{array}$ \\
\hline Ülkü (2004) & $\begin{array}{l}1981- \\
1997\end{array}$ & $\begin{array}{l}30 \text { Ülke }(20 \\
\text { OECD, } 10 \\
\text { OECD Üyesi } \\
\text { Olmayan) }\end{array}$ & $\begin{array}{ll}\text { - } & \text { Ar-Ge Harc. } \\
\text { - } & \text { Patent Say1s1 } \\
\text { - } & \text { GSYH }\end{array}$ & $\begin{array}{l}\text { Ar-Ge harç. ve patent } \\
\text { sayısı ile GSYH arasında } \\
\text { istatistiksel pozidian } \\
\text { anlamlı pozilişki } \\
\text { olduğu sonucuna } \\
\text { ulaşılmıştır }\end{array}$ \\
\hline
\end{tabular}




\begin{tabular}{|c|c|c|c|c|}
\hline Çalışma & Y11 & Ü1ke Sayısı & Değişkenler & Bulgular \\
\hline $\begin{array}{l}\text { Özer ve Çiftçi } \\
(2008)\end{array}$ & $\begin{array}{l}1990- \\
2005\end{array}$ & $\begin{array}{l}\text { OECD Üyesi } \\
\text { Ülkeler }\end{array}$ & $\begin{array}{ll}\text { - } & \text { Ar-Ge Harc. } \\
\text { - } & \text { Patent Say1s1 } \\
\text { - } & \text { GSYH }\end{array}$ & $\begin{array}{l}\text { Ar-Ge harç. ve patent } \\
\text { sayısının GSYH üzerinde } \\
\text { güçlü ve pozitif bir etkisi } \\
\text { olduğu sonucuna } \\
\text { ulaşılmıştır. }\end{array}$ \\
\hline Saraç (2009) & $\begin{array}{l}1983- \\
2004\end{array}$ & $\begin{array}{l}10 \text { OECD } \\
\text { ülkesi }\end{array}$ & $\begin{array}{l}\text { - Ar-Ge Harc. } \\
\text { - Ekon. } \\
\text { Büyüme }\end{array}$ & $\begin{array}{l}\text { Ar-Ge harc. ekonomik } \\
\text { büyümeyi pozitif yönde } \\
\text { etkilediği } \\
\text { ulaşılmıştır. }\end{array}$ \\
\hline $\begin{array}{l}\text { Genç ve Atasoy } \\
(2010)\end{array}$ & $\begin{array}{l}1997- \\
2008\end{array}$ & 34 ülke & $\begin{array}{l}\text { - Ar-Ge Harc. } \\
\text { - Ekon. } \\
\text { Büyüme }\end{array}$ & $\begin{array}{l}\text { Ar-Ge harç. } \\
\text { büyüme üzerinde etkisi } \\
\text { olduğu saptanmıştır. }\end{array}$ \\
\hline $\begin{array}{l}\text { Güloğlu ve } \\
\text { Tekin (2012) }\end{array}$ & $\begin{array}{l}1991- \\
2007\end{array}$ & $\begin{array}{l}13 \text { OECD } \\
\text { ülkesi }\end{array}$ & $\begin{array}{l}\text { - Ar-Ge Harc. } \\
\text { - Patent Say1sı } \\
\text { - Ekon. } \\
\text { Büyüme }\end{array}$ & $\begin{array}{l}\text { Ar-Ge harç. ve patent } \\
\text { sayılarının ekonomik } \\
\text { büyüme üzerinde önemli } \\
\text { bir etkisi olduğu } \\
\text { görülmüştür. }\end{array}$ \\
\hline $\begin{array}{l}\text { Gülmez ve } \\
\text { Yardimcioğlu } \\
\text { (2012) }\end{array}$ & $\begin{array}{l}1990- \\
2010\end{array}$ & $\begin{array}{l}21 \text { OECD } \\
\text { ülkesi }\end{array}$ & $\begin{array}{l}\text { - Ar-Ge Harc. } \\
\text { - Ekon. } \\
\text { Büyüme }\end{array}$ & $\begin{array}{l}\text { Ar-Ge harç. ekonomik } \\
\text { büyüme üzerinde uzun } \\
\text { dönemli etkisi olduğu } \\
\text { saptanmıştır. }\end{array}$ \\
\hline $\begin{array}{l}\text { Gülmez ve } \\
\text { Akpolat (2014) }\end{array}$ & $\begin{array}{l}2000- \\
2010\end{array}$ & $\begin{array}{l}\text { Türkiye ve } 15 \\
\text { AB ülkesi }\end{array}$ & $\begin{array}{l}\text { - Ar-Ge Harc. } \\
\text { - Patent Sayısı } \\
\text { - Ekon. } \\
\text { Büyüme }\end{array}$ & $\begin{array}{l}\text { Ar-Ge harç. ve patent } \\
\text { sayılarının ekon. büyüme } \\
\text { üzerinde etkisi olduğu, } \\
\text { daha spesifik olarak, Ar- } \\
\text { Ge harcamalarının } \\
\text { etkisinin patent sayısına } \\
\text { göre } 4 \text { kat daha fazla } \\
\text { olduğu sonucuna } \\
\text { ulaşılmıştır. }\end{array}$ \\
\hline
\end{tabular}

\section{Ekonometrik Analiz}

Çalışmanın analiz kısmında, inovasyon ile ekonomik büyüme arasındaki uzun dönemli ilişki seçili G7 ülkeleri üzerinden test edilmektedir. Bu kapsamda öncelikle kurulan hipotez çerçevesinde kullanılacak değişkenlere ait veri seti ve model tanıtılmakta, kullanılacak yöntem belirlenmekte ve yöntem kapsamında kullanılacak testlerin teorik ve kavramsal çerçevesi sunulduktan sonra elde edilen bulgular yorumlanmaktadır.

Araştırmada temel hipotez şu şekilde kurulanmıştır:

"İnovasyon ile ekonomik büyüme arasinda orta ve uzun dönemli eşbütünleşme ve nedensellik ilişkisi vardır."

Ekonomik büyüme olarak literatür ile uyumlu bir şekilde milli gelirdeki değişim oranını ifade eden ülkelerin büyüme oranları alınmıştır. Büyüme oranı, kurulan modelde bağımlı değişken olarak alındığı için ekonomik büyümeyi etkileyen kontrol değişkenler sabit varsayılarak ve çoklu doğrusallık sorununun da önüne geçmek amacıyla sadece milli gelirdeki değişim modellenmiştir. Ayrıca model kurgulanırken, literatürde Wang (2007), Yanyun ve Mingquian (2004), Özer ve Çiftçi (2008), Gülmez ve Akpolat (2014), Ülkü (2004), vb. çalışmalardan da 
faydalanılarak değişkenler belirlenmiştir. Bu kapsamda inovasyon değişkeni olarak ise literatürde en çok kullanılan inovasyon göstergelerinden ar-ge harcamaları ve patent başvuruları kullanılmıştır. Bu nedenle temel hipoteze ek olarak;

"Ekonomik büyüme ile ar-ge harcamaları arasında orta ve uzun dönemli ilişki vardır" ve "ekonomik büyüme ile patent başvuruları arasında orta ve uzun dönemli ilişki vardır." şeklinde kurgulanan alt hipotezler de gerçekleştirilen analizler 1şı̆̆ında test edilmektedir.

Çalışmanın örneklemini G7 ülkeleri (Kanada, Fransa, Almanya, İtalya, Japonya, Birleşik Krallık, ABD) olussturmakta olup 1981-2016 dönemlerine ait yıllık veriler kullanılarak ekonometrik testler ile analizler gerçekleştirilmiştir. G7 ülkeleri arasından İtalya'nın inovasyon değisskeni için diğer ülkeler ile ortak verilere sahip olmaması yani veri kısıtı nedeniyle kapsam dışı bırakılmıștır. Dolayısıyla analize toplam 6 ülke dâhil edilmiştir.

Modele dâhil edilen değişkenlerden ekonomik büyüme (BO), ilgili ülkelerin milli gelirindeki değissim oranlarını ifade etmektedir. Modelde inovasyon değişkeni olarak ise patent başvuru sayısı (PAT) ve Ar-Ge harcamaları (ARGE) kullanılmıştır. Patent başvuru sayısı değişkeni olarak ilgili ülkede belirtilen dönemler itibariyle yerli ve yabancı patent başvuru sayısı hesaplanırken, Ar-Ge harcaması değişkeni olarak da ülkelerin ilgili dönemlerde milli gelirden ar-ge ye ayırdıkları oranlar analizde dâhil edilmiştir. Ayrıca patent sayısı değişkeninin logaritması alınarak doğrusal hale getirilmiş ve daha sonra analize dâhil edilmiştir.

Analizlerde kullanılan ARGE değişkeni OECD, diğer değişkenler ise Dünya Bankası veri tabanından elde edilmiş olup ikincil verilerdir.

İnovasyon ile ekonomik büyüme arasındaki ilişkinin incelendiği çalışmada, belirtilen örneklem ve veri aralığında kullanılan model şu şekilde kurgulanmıştır;

$$
B O_{t}=\beta_{0}+\beta_{1} A R G E_{i t}+\beta_{1} \ln P A T_{i t}+\varepsilon_{i t}
$$

Modelde gösterilen $\mathrm{i}=1,2,3, \ldots \mathrm{N}$ yatay kesit verilerini gösterirken, $\mathrm{t}=1,2$, $3, \ldots .$. T zaman boyutunu, $\varepsilon$ ise hata terimini ifade etmektedir.

G7 ülkeleri üzerinde inovasyon ile ekonomik büyüme arasındaki ilişkinin incelendiği çalışmada panel veri analizi kullanılmış olup uygulanan metodolojik sıralama şu şekildedir;

- Değişkenlerin yatay kesit bağımlılı̆̆ının varlığının analizi için Pesaran vd (2008)'in LMadj testi,

- Modele dâhil edilen değişkenlerin birim kök içerip içermediği Pesaran (2007)'in CADF durağanlık testi,

- Eğim katsayılarının birimler arasında değissip değişmediğinin tespiti için Pesaran ve Yagamata (2008) nın geliştirdiği Delta testi,

- Modele dâhil edilen değişkenler arasında eşbütünleşme ilişkisinin varlığının tespiti için Westerlund (2008)'un geliştirdiği Durbin-Hausman eşbütünleşme testi

- Eşbütünleşme testlerinin sonuçlarının ardından eşbütünleşme katsayılarının tahmininde CCE ile AMG tahmincisi

- Son olarak ise nedensellik testi için ise Dumitrescu-Hurlin (2012) panel nedensellik testi kullanılarak analizler gerçekleştirilmiştir. 


\subsection{Yatay Kesit Bağımlılı̆̆ Testi}

Panel veri analizinde öncelikli olarak seriler arasında yatay kesit bağımlılığı olup olmadığına bakılır. Değişkenler arasında yatay kesit bağımlılığı mevcut ise ve bu durum önemsenmeden analizler gerçekleştirilirse analiz sapmalı ve tutarsız sonuçlar verecektir (Breusch and Pagan: 239, 1980; Pesaran, 2004:1).

Seriler arasında yatay kesit bağımlılığı Berusch-Pagan (1980) LM testiyle veya Pesaran (2004) CD testiyle analiz edilebilir. Berusch-Pagan (1980) LM testi zaman boyutu yatay kesit boyutundan büyük olduğunda $(\mathrm{T}>\mathrm{N})$ uygulanabilirken, Pesaran (2004) CD testi ise her durumda uygulanabilir.

$$
C D L M 1=T \sum_{i=1}^{N-1} \sum_{j=i+1}^{N} \hat{\rho}_{i j}^{2} \sim \frac{\chi_{\frac{N(N-1)}{2}}^{2}}{2}
$$

$\mathrm{Bu}$ testler, grup ortalaması sıfır ve bireysel ortalama sıfırdan farklı olduğu durumlarda sapmalı sonuçlar vermektedir. Bu sorun Pesaran vd. (2008) tarafindan test istatistiğine varyans ve ortalamanın dâhil edilmesi ile düzeltilmiştir. Bu nedenledir ki sapması düzeltilmiş olan denklem LM $_{\text {adj şeklinde }}$ ifade edilmiştir.

Tablo 2: Yatay Kesit Bağımlılı̆̆ı Testi Sonuçları

\begin{tabular}{|c|c|c|c|c|c|}
\hline Değişkenler & CD Testleri & $\begin{array}{c}C D_{\operatorname{lm} 1} \\
(B P, 1980)\end{array}$ & $\begin{array}{c}C_{1 m 2} \\
\text { (Pesaran, } \\
\text { 2004) }\end{array}$ & $\begin{array}{c}\text { CD } \\
\text { (Pesaran, } \\
\text { 2004) }\end{array}$ & $\begin{array}{c}\mathbf{L M}_{\mathrm{adj}} \\
\text { (Pesaran vd., } \\
\text { 2008) }\end{array}$ \\
\hline \multirow{2}{*}{ BO } & T İstatistiği & 1.194 .725 & 1.907 .398 & 9.462 .404 & 1.898 .307 \\
\hline & Olasıl1k Değeri & $0.0000^{*}$ & $0.0000^{*}$ & $0.0000^{*}$ & $0.0000^{*}$ \\
\hline \multirow{2}{*}{ ARGE } & T İstatistiği & 1.099 .293 & 1.733 .164 & 1.775 .508 & 1.724 .073 \\
\hline & Olasılık Değeri & $0.0000^{*}$ & $0.0000^{*}$ & $0.0000^{*}$ & $0.0000^{*}$ \\
\hline \multirow{2}{*}{ InPAT } & $\mathrm{T}$ İstatistiği & 1.547 .117 & 2.550 .776 & 1.930 .547 & 2.541 .685 \\
\hline & Olasılık Değeri & $0.0000 *$ & $0.0000^{*}$ & $0.0535^{* * *}$ & $0.0000^{*}$ \\
\hline
\end{tabular}

Not: * ** ve *** serilerin sirasıyla \% 1, \%5 ve \% 10 düzeyinde yatay kesit bağımlılı̆̆ının olduğunu göstermektedir. Parantez içindeki değerler olasılık değerlerini ifade etmektedir.

Yatay kesit bağımlılığı test sonuçlarının gösterildiği Tablo 2 incelendiğinde uygulanan tüm testlerin olasılik değerlerinin 0.05'ten küçük olduğu görülmektedir. Çalışmada, inovasyon göstergesi olarak belirlenen Ar-Ge harcamaları (ARGE) ve patent başvurusu sayısı (lnPAT) değişkenleri ile büyüme oranı (BO) arasındaki ilişki G7 ülkeleri üzerinden 1981-2016 yılları arasındaki dönemlerde incelendiği için zaman boyutu gözlem boyutundan büyüktür. Analize dahil edilen ülke sayıs 6 iken zaman boyutu ise 34 dür. $(T>N)$ olduğundan $C D_{\operatorname{lm} 1}$ ve $\mathrm{LM}_{\mathrm{adj}}$ sonuçlarına göre karar verilebilmektedir. Yatay kesit bağımlılı̆̆ testlerinde genellikle $\mathrm{CD}_{\operatorname{lm} 1}$ testi, sapmalı sonuçlar verebildiğinden dolayı $\mathrm{LM}_{\mathrm{adj}}$ testi sonuçları dikkate alınmaktadır. LM $_{\text {adj }}$ testi sonuçlarına göre, temel hipotez olan "Kesitler arasında bağımlılık yoktur." kuramı reddedilerek, panel veride yer alan "Ülkeler arasında yatay kesit bağımlılığı bulunmaktadır." hipotezi kabul edilir. Değişkenlerde yatay kesit bağımlılığının tespit edilmesinden dolayı bundan sonra uygulanacak birim kök ve eşbütünleşme testlerinde ikinci nesil testler tercih edilmektedir. 
Bu durum günümüz küresel dünyası ile de uyumlu olup G7 ülkelerinden birine gelebilecek bir şok etkisi, diğer ülkeleri de etkisi altına alacağı sonucunu vermektedir. Bu nedenle, gerek G7 ülkelerinin geleceğini kurgulayan yöneticiler gerekse de G7 ülkeleri, kendi politikalarını geliştirirken bu durumu dikkate alarak geleceğe yön vermesi gerekmektedir. Bu sonucun en bariz örneği Şekil 1 ve Şekil 2 de net bir şekilde görülmektedir. Özellikle 2008 küresel krizinin yarattığ dalgalanmalar G7 ülkelerinin ekonomik büyümesini olumsuz yönde etkilemiștir. Konjonktürel dalgalanmalar karşısında güçlü bir ekonomik yap1 ve küresel rekabette ayakta kalabilecek yenilikçi politikalar geliştirilmesi G7 ülkeleri için de büyük önem arz etmektedir. Çünkü dünya ekonomisinde büyük ağırlığı olan bu ülkelerde yaşanılabilecek şoklar, küresel dalgalanmalara neden olabilecektir.

\subsection{Durağanlık Testi}

Durağanllk testleri (birim kök testleri), birinci ve ikinci kuşak testleri olmak üzere iki şekilde yapılmaktadır. Birinci kuşak birim kök testleri, homojen ve heterojen modeller şeklinde ikiye ayrılmaktadır. Birinci kuşak testler de yatay kesit bağımlılığının olmadığı yani paneli oluşturan yatay kesit birimlerinin birbirinden bağımsız olduğu ve bu birimlerden herhangi birine gelen değişimden, diğer yatay kesit birimlerinin aynı oranda etkilendikleri varsayımına dayanmaktadır. Ancak, günümüz küresel koşulları dikkate alındığında, paneli oluşturan yatay kesit birimlerinden herhangi birinde meydana gelen değişimden diğer birimlerin farklı düzeyde etkilendiği daha gerçekçi bir değerlendirme olacaktır.

Bu çalışma kapsamında ikinci nesil birim kök testlerinden Pesaran (2007) tarafından geliştirilen CADF testi kullanılacaktır. CADF ile modeldeki tüm kesitler için ayrı ayrı birim kök testi uygulanabilmektedir. Yani serilerin birim köklü olup olmadığı hem panelin geneli hem de her kesit için ayrı ayrı hesaplanabilmektedir. Ülkelerin zaman etkisinden farklı düzeyde etkilendiği varsayımına dayanan ve mekânsal otokorelasyonu göz önünde bulunduran CADF testi, test istatistiği değerleri, Pesaran (2007)'in CADF kritik tablo değerleriyle karşılaştırılmakta ve her ülke için durağanlık testi yapılmaktadır. Bahse konu tablodaki CADF değeri, analiz sonucunda elde edilen CADF değerinden büyükse sıfır hipotezi reddedilir. CADF test istatistiği tahminlemesi aşağıda denklem 2'de verilmiştir;

$$
\begin{aligned}
& Y_{i, t}=\left(1-\emptyset_{i}\right) \mu_{i}+\emptyset_{i} y_{i, t-1}+u_{i, t} \\
& i=1,2, \ldots \ldots, N \text { ve } t=1,2, \ldots, T \\
& u_{i t}=\gamma_{i} f_{t}+\varepsilon_{i t} \\
& f_{t}=\text { Her ülkenin gözlenemeyen ortak etkilerini (common effect), } \\
& \varepsilon_{i t}=\text { Bireysel-spesifik hata }
\end{aligned}
$$

Son olarak, her bir ülkeye ait birim kök test istatistiklerinin ortalamas1 alınarak panelin tamamı için birim kök test istatistiği hesaplanır. CIPS (CrossSectionally Augmented CIPS) ile ifade edilen istatistik değeri aşağıdaki denklem 3 ile hesaplanmaktadır (Pesaran, 2007: 276);

$$
C I P S=N^{-1} \sum_{i=1}^{N} C A D F_{i}
$$


Tablo 3: CADF Birim Kök Testi Sonuçları

\begin{tabular}{|l|c|c|c|c|c|c|}
\hline \multirow{2}{*}{ Değişkenler } & \multicolumn{5}{|c|}{ Düzey } & \multicolumn{3}{c|}{ Birinci Fark } \\
\hline Ülkeler & BO & ARGE & lnPAT & $\Delta$ BO & $\Delta$ ARGE & $\Delta$ lnPAT \\
\hline Kanada & $-3.62(2)^{* * *}$ & $-0.591(2)$ & $-3.084(2)$ & $-5.386(2)^{*}$ & $-3.060(2)$ & $-4.756(2)^{*}$ \\
\hline Fransa & $-3.40(2)$ & $1.377(2)$ & $-3.721(2)^{* * *}$ & $-3.486(3)$ & $-0.762(2)$ & $-3.386(2)$ \\
\hline Almanya & $-0.783(4)$ & $-0.219(4)$ & $-3.391(4)$ & $-2.227(4)$ & $-2.890(2)$ & $-1.668(2)$ \\
\hline Japonya & $2.44(2)$ & $-1.201(3)$ & $-3.278(3)$ & $-5.053(2)^{*}$ & $-4.126(4)^{* *}$ & $-4.153(3)^{* *}$ \\
\hline İngiltere & $-3.79(3)^{* * *}$ & $-1.597(2)$ & $-3.407(3)$ & $-6.366(2)^{*}$ & $-4.758(2)^{*}$ & $-3.160(2)$ \\
\hline ABD & $-3.30(2)$ & $-3.687(2)^{* * *}$ & $-2.424(2)$ & $-4.179(2)^{* *}$ & $-4.664(2)^{* *}$ & $-4.050(2)^{* *}$ \\
\hline \begin{tabular}{l} 
CIPS İstatistiği \\
\hline
\end{tabular} & $-2.89 * *$ & -0.986 & $-3.218^{*}$ & $-4.449 *$ & $-3.377^{*}$ & - \\
\hline
\end{tabular}

Not: Parantez içindeki değerler gecikme uzunluklarını göstermektedir. Sabitli ve trendli model için test istatistikleri hesaplanmıştır. * ${ }^{* *}$ ve $* * * \% 1, \% 5$ ve $\% 10$ anlamlllık düzeyinde serilerin durağan olduğunu göstermektedir. CADF için \%1, \%5 ve \%10 kritik değerler sırasıyla $-4.67,-3.87$ ve 3.49'dur. CIPS için \% 1, \%5 ve \%10 kritik değerler sırasıyla $-3.10,-2.86$ ve -2.73 'tür.

Test sonuçları incelendiğinde, düzey değerlerinde ülkeler ile panelin geneli bazı değişkenlerde birim köklü bazı değişkenlerde ise durağan çıkmıştır. Bunlar incelendiğinde; BO değişkeni için Kanada ve İngiltere, ARGE değişkeni için sadece $\mathrm{ABD}, \ln$ PAT değişkeni için ise sadece Fransa ülkeleri düzey değerlerinde durağan çıkmıştır. Panelin geneline bakıldığında ise düzey değerlerinde ARGE değişkeni birim köklü iken diğer değişkenler durağan görünmektedir. Değişkenler arasında eşbütünleşme ilişkisine bakılabilmesi için serilerin aynı mertebeden ya da bağımlı değişkenin birinci dereceden durağan çıkması gerekmektedir. Bu nedenle modele dahil edilen değişkenleri durağan hale getirmek için birinci dereceden farkı alınmıştır. Farkı alınan serilere bakıldığında ise panelin geneli için tüm değişkenlerin \%1 anlamlılık düzeyinde durağan hale geldiği, ülkelerin ise büyük kısmının durağanlaştığ görülmektedir. Birim kök test sonuçlarına göre, BO ve ARGE değişkenlerinin birinci dereceden farkı alındığında, lnPAT değişkeninin ise düzey değerinde I(0) durağan hale gelmektedir. Değişkenlerin farklı mertebelerden durağan olduğu görülmekte; ancak, bağımlı değişkenin I(1) ve diğer değişkenlerin farklı durağanlık derecelerinin olması şartıyla uygulanabilen Durbin-Hausman eşbütünleşme yapılabilmesi için gerekli olan önkoşulun sağlandığı söylenebilir.

\subsection{Homojenite Testi}

Son dönemde, Pesaran ve Yamagata (2008) tarafından N ve T'nin büyüklükleri dikkate alınmaksızın ve homojenite varsayımını analiz edebilecek iki homojenite testi geliştirilmiştir. Örneğin, aşağıda verilen eş-bütünleşme modelinde $\beta i$ katsayılarının yatay kesit birimleri arasında homojen olup olmadığ delta testiyle sinanmaktadir.

$$
Y i t=\alpha+\beta i X i t+\varepsilon i t
$$

Diğer taraftan Pesaran ve Yamagata (2008) tarafindan büyük örneklemler için aşağıda verilen denklem geliştirilmiştir. Küçük örneklemler için geçerli 2 delta istatistiği geliştirmişlerdir.

$$
\Delta=\sqrt{ } N(N-1 S \square-k 2 k) \sim X k 2
$$


Aynı yazarlar tarafından geliştirilen ve küçük örneklemler için kullanılan eşitlik ise aşağıda verilmiştir.

$$
\Delta^{\wedge} \text { adj }=\sqrt{ } N(N-1 S \square-k v(T, k)) \sim N(0,1)
$$

Ekonomik büyüme ile inovasyon arasında ilişkinin analiz edildiği çalışmada kurulan modele göre eğim katsayılarının birimler arasında değişip değişmediğinin tespiti için Delta homojenite testi gerçekleştirilmiş olup elde edilen bulgular Tablo 4’te gösterilmiştir.

Tablo 4: Homojenite Testi Sonuçları

\begin{tabular}{|l|c|c|}
\hline Test İstatistiği & T İstatistiği & Olasılık Değeri \\
\hline Delta_tilde & 2.244 & 0.012 \\
\hline Delta_tilde_adj & 2.384 & 0.009 \\
\hline
\end{tabular}

Test sonuçlarına göre her iki test istatistiğinin olasılık değerinin 0.05 'ten küçük olduğu için uzun dönemde birimler arasında eğim katsayıları değiştiği bu nedenle değişkenlerin heterojen olduğu sonucuna ulaşlmıştır. Değişkenlerin heterojen olmasından dolayı değişkenler arası ilişkilerin analizinde panel değil de grup istatistiklerinin kullanılmas1 gerekmektedir.

\subsection{Panel Eşbütünleşme Testi}

Ekonometrik analizlerde değişkenler arasında ki orta ve uzun dönemli ilişkinin tespiti için eşbütünleşme testleri kullanılmaktadır. Çalışmada, Westerlund (2008) tarafindan geliştirilen Durbin-Hausman panel eş bütünleşme analizi test edilmiştir. Durbin-Hausman panel eş bütünleşme testi, imalat sanayinde üretim artış1, ekonomik büyüme, işgücü verimlilik artış1 gibi seriler arasındaki eş bütünleşme ilişkisi analizinde ve seriler arasında yatay kesit bağımlılığının var olduğu durumlarda kullanılabilmektedir. Modele göre; bağımlı değişken I(1) olmak şartıyla, bağımsız değişkenlerin I(1) veya I(0) olması durumunda panel eş bütünleşme analizi yapılmasına olanak tanımakta ve ortak faktörleri dikkate almaktadır (Westerlund, 2008: 218).

Durbin-Hausman eşbütünleşme testinde, ilişki grup ve panel boyutunda ayr1 ayr1 analiz edilebilmektedir. D-H grup testi, otoregresif parametrenin yatay kesitler arasında değişmesine izin vermektedir. Analizde $H_{0}$ hipotezinin kabul edilmemesi, bazı kesitler için eşbütünleşme ilişkisinin varlığını göstermektedir. D$\mathrm{H}$ panel eşbütünleşme testinde ise ororegresif parametrenin tüm kesitler için benzer olduğu kabul edilerek analizler gerçekleștirilmektedir. Bu bilgiler 1șığında $H_{0}$ hipotezinin kabul edilmemesi kesitler arasında orta ve uzun dönemli eşbütünleşme ilişkisinin var olduğu şeklinde yorumlanmaktadır (Di Iorio ve Fachin, 2008: 7).

Panel veri modeli aşağıdaki denklem 5-6 ile ifade edilmektedir;

$$
\begin{aligned}
& y_{i t}=\alpha_{i}+\beta_{i} x_{i t}+z_{i t} \\
& x_{i t}=\delta X_{i t-1}+w_{i t}
\end{aligned}
$$

Son olarak, Durbin-Hausman testi için gerekli olan çekirdek tahminci aşağıdaki denklem 7 ile elde edilmektedir.

$$
\widehat{\omega}_{i}=\frac{1}{T-1} \sum_{j=M_{i}}^{M_{i}}\left(1-\frac{j}{M_{i}+1}\right) \sum_{t=j+1}^{T} \hat{v}_{i t} \hat{v}_{i t-j}
$$


Tablo 5: Panel Eşbütünleşme Testi Sonuçları

\begin{tabular}{|l|c|c|}
\hline Test İstatistiği & T İstatistiği & Olasılık Değeri \\
\hline Durbin-H Grup İstatistiği & 2.343 & $0.012^{*}$ \\
\hline Durbin-H Panel İstatistiği & -1.368 & 0.914 \\
\hline
\end{tabular}

Eğim katsayılarının değiştiği ve değişkenlerin heterojen olduğu modelde, değişkenler arasındaki uzun dönemli ilişkinin tespiti için ikinci nesil ekonometrik testlerden Durbin-Hausman eşbütünleşme testi kullanılmıştır. Homojenite testinden elde edilen sonuçlar incelendiğinde, grup istatistiklerinin kullanılmasının daha uygun olacağı tespit edildiğinden, Durbin-H Grup istatistiği sonuçları dikkate alınmaktadır. Durbin-H Grup istatistiğinin olasılık değerleri incelendiğinde 0.05 ten küçük olmasından dolayı değişkenler arasında uzun dönemli bir ilişkinin olduğu sonucuna ulaşılmaktadır. Değişkenler arasındaki uzun dönemli ilişkinin tespiti G-7 ülkeleri için önemli politika değişikliklerini getirmektedir. İnovatif gelişmelerin orta ve uzun dönemde ekonomik büyümeyi etkilediği ve yapılabilecek bir ar-ge faaliyetinin ya da patent sürecinin ekonomik büyüme üzerinde etkili olduğu sonucu çıkarılmaktadır. Küresel rekabet de daha güçlü olabilmek için bu eşbütünleşme ilişkisinden çıkarılacak en önemli sonuçlardan biri de milli gelirden ar-ge ye ayrılan payın daha da arttırılması gereğidir. Ar-Ge harcamaları orta ve uzun dönemde etkisini gösteren ve ekonomik büyümede, küresel rekabette önemli avantajlar yaratan bir güçtür. Bu nedenle dünya ekonomisinde büyük ağırlığı olan G-7 ülkelerinin yenilikçi politikalara daha fazla bütçe ayırması dünya ekonomisi içinde oldukça önemlidir.

Seriler arasında eş bütünleşme ilişkisi test edildikten sonra uzun dönemde bireysel eş bütünleşme katsayılarının belirlenmesi gerekmektedir. Bu kapsamda, Eberhardt ve Bond (2009) tarafından geliştirilen AMG (Augmented Mean Group Estimator: Güçlendirilmiş Ortalama Grup Etkisi) yöntemi veya Pesaran (2006) tarafından geliştirilen CCE (Common Corelated Effects: Ortak Grup Etkisi) yöntemi kullanılmaktadır.

Bu yöntemlerden ilki olan AMG yöntemi serilerin I(1) olması durumunda kullanılabilen paneli oluşturan ülkelere ve panelin geneline ait eş bütünleşme katsayılarını hesaplayabilen bir tahmincidir. Bu yöntemde panelin geneli için geçerli olan uzun dönem eş bütünleşme katsayıs1, yatay kesitlere (ülkelere) ait uzun dönem eş bütünleşme katsayılarının aritmetik ortalaması ağırlıklandırılarak tahmin edilmektedir. Bu nedenle $\mathrm{CCE}$ tahmincisinden daha güvenli sonuçlar vermektedir. İlave olarak, değişkenlerin ortak faktörlerini ve dinamik etkilerini dikkate aldığından, dengesiz panel analizlerinde de etkin sonuçlar veren bir yöntemdir. Son olarak, hata teriminden kaynaklanan içsellik probleminin olması halinde de kullanılabilen (Eberhardt ve Bond, 2009: 2-3) AMG tahmincisi değişkenleri aşağıda verilmiştir;

$$
\begin{aligned}
& y_{i t}=\beta_{i}^{l} x_{i t}+u_{i t} \\
& u_{i t}=\alpha_{i}+\lambda_{i}^{l} f_{t}+\varepsilon_{i t} \quad(i=1 \ldots . N, t=1 \ldots . T, m=1 \ldots k) \\
& x_{m i t}=\pi_{m i}+\delta_{m i}^{l} g_{m t}+\rho_{1 m i} f_{1 m t}+\cdots .+\rho_{n m i} f_{n m t}+v_{i t} \\
& f_{t}=\tau^{l} f_{t-1}+\varepsilon_{i t} \text { ve } g_{t}=\Psi^{l} g_{t-1}+\Omega_{i t}
\end{aligned}
$$


İbrahim ÇÜTÇÜ \& Turgay BOZAN

Tablo 6: Panel Eşbütünleşme Katsayıları Tahmin Sonuçları

\begin{tabular}{|c|c|c|c|c|c|c|}
\hline \multirow{2}{*}{$\begin{array}{c}\text { Bağımsız } \\
\text { Değişkenler }\end{array}$} & \multicolumn{3}{|c|}{ CCE Tahmincisi } & \multicolumn{3}{|c|}{ AMG Tahmincisi } \\
\hline & Katsayı & $\begin{array}{l}\text { Standart } \\
\text { Hata }\end{array}$ & Olasılık & Katsayı & $\begin{array}{l}\text { Standart } \\
\text { Hata }\end{array}$ & Olasılık \\
\hline ARGE & -4.2076 & 1.6251 & $0.010 *$ & -2.8631 & 1.5066 & $0.057 * * *$ \\
\hline $\ln P A T$ & 0.5051 & 3.0772 & 0.870 & -1.1067 & 2.4471 & 0.651 \\
\hline
\end{tabular}

Not: *,** ve *** sirasıyla \%1, \%5 ve \%10 anlamlılık düzeyinde katsayıların istatistiki olarak anlamlı olduğunu göstermektedir.

Katsayı tahmincisi olarak kullanılan CCE ve AMG testlerinin sonuçları kontrol edildiğinde her ikisinin de birbiriyle uyumlu olduğu görülmektedir. Bağımsız değişken olarak belirlenen ARGE değişkeni ile bağımlı değișken olarak belirlenen $\mathrm{BO}$ arasinda hem $\mathrm{CCE}$ hem de AMG tahmincisine göre negatif yönlü ilişki tespit edilmiştir. İlişkinin yönü Ar-Ge'den büyüme oranına negatif yönlü olup bu durum beklentiler dişındadır. Katsayılar yorumlandığında ise CCE tahmincisine göre Ar-Ge harcamalarında ki \%1'lik artışın ekonomik büyüme de \%4,2'lik azalmaya, AMG tahmincisine göre ise Ar-Ge harcamalarındaki \%1'lik artışın ekonomik büyümede \%2,86'lık azalmaya neden olacağı söylenebilir.

$\mathrm{Bu}$ durum G7 ülkelerinin sosyo-ekonomik gücünden kaynaklı olduğu düşünülmektedir. Çünkü analize dâhil edilen ülkeler, ekonomik açıdan oldukça güçlü olup bütçelerinden Ar-Ge'ye ayrılacak payların ekonomik büyümelerini olumsuz yönde etkileyebilir şeklinde yorumlanabilir. lnPAT değişkeninin katsayısının olasılık değerinin ise istatistiki olarak anlamsız çıktığı görülmektedir.

\subsection{Panel Nedensellik Testi}

Son olarak, Dumitrescu-Hurlin (2012) panel nedensellik testi değişkenler arasındaki nedensellik ilişkisini analiz etmek için kullanılır. Bu test hem $\mathrm{T}>\mathrm{N}$ hem de $\mathrm{T}<\mathrm{N}$ durumlarında kullanılabilmektedir. Diğer bir avantajı ise, yatay kesit bağımlılığını dikkate aldığından panel verisine sahip olunan durumlarda daha etkin sonuçlar vermesidir. Panel nedensellik testi, hem regresyon modelini hem de nedensellik ilisskisini dikkate alarak homojen nedensellik ilişkisi olmadığ varsayımını kullanır. Alternatif hipotez şu şekilde tanımlanmaktadır (DumitrescuHurlin, 2012: 1451-1454);

$$
H_{0}: \beta_{i}=0, \quad \forall_{i}=1,2, \ldots . N
$$

$\mathrm{Bu}$ eşitliğe göre $\beta_{\mathrm{i}}$ değeri $\beta_{i}=\left(\beta_{i}^{(1)}, \beta_{i}^{(2)} \ldots . . \beta_{i}^{(k)}\right)$ şeklinde devam etmekte olup, gruplar arasında farklılık gösterebilir. Test aynı zamanda bazı bireysel vektörlerin ( $\mathrm{Bi}$ ) “ 0 ” a eşit olduğu varsayımı ile çalışır. Sıfır hipotezinde $\mathrm{N}_{1}<\mathrm{N}$ adet x'ten y'ye bir nedensellik olmayan bireysel süreç mevcuttur. Alternatif hipotez şu şekilde ifade edilmektedir.

$$
\begin{aligned}
H_{1}: \beta_{i} & =0, \quad \forall_{i}=1,2, \ldots . N_{1} \\
\beta_{i} & \neq 0, \quad \forall_{i}=N_{1}+1, \ldots, N
\end{aligned}
$$

$\mathrm{Bu}$ denklemde $\mathrm{N}_{1}$ değeri bilinmemekle beraber $0 \leq \mathrm{N}_{1} / \mathrm{N}<1$ şartını sağlamaktadır. $\mathrm{N}_{1} / \mathrm{N}$ oranı 1'den küçük olmalıdır, çünkü $\mathrm{N}_{1}=\mathrm{N}$ durumunda panelin değişkenleri arasında herhangi bir nedensellik ilişkisi olmadığı anlamına 
gelmektedir. Diğer taraftan, $\mathrm{N}_{1}=0$ durumunda tüm değişkenler arasında bir nedensellik ilişkisi olduğu manasına gelmektedir.

Sifır hipotezinin testinde ilk olarak Wald istatistiği $\left(W_{i}, T\right)$ tüm çapraz kesitler için hesaplanır ve panel Wald istatistiğini $\left(W_{N, T}^{H N C}\right)$ hesaplamak için her birinin ortalaması alınır. Son olarak, Dumitrescu-Hurlin (2012), $T>N$ durumunda $Z_{N, T}^{H N C}$ istatistiğini, diğer durumda ise $Z_{N}^{H N C}$ test istatistiğini kullanmak durumundadir.

$$
\begin{aligned}
Z_{N, T}^{H N C} & =\sqrt{\frac{N}{2 K}\left(W_{N, T}^{H N C}-K\right)} \\
Z_{N}^{H N C} & =\frac{\sqrt{N\left[W_{N, T}^{H N C}-N^{-1} \sum_{i=1}^{N} E\left(W_{i, T}\right)\right]}}{\sqrt{N^{-1} \sum_{i=1}^{N} \operatorname{Var}\left(W_{i, T}\right)}}
\end{aligned}
$$

İnovasyon ile ekonomik büyüme arasındaki ilişkinin araştırıldığı çalışmada, değişkenler arasındaki uzun dönemli ilişkinin tespiti modele dâhil edilen değişkenler arasındaki nedenselliğin varlığı ve yönü hakkında bilgi vermemektedir. Bu nedenle ekonometrik çalışmalarda eşbütünleşme ilișkisinin tespit edilmesinin ardından nedensellik analizlerinin de gerçekleştirilmesi gerekmektedir.

Tablo 7: Panel Nedensellik Testi Sonuçları

\begin{tabular}{|c|c|c|c|}
\hline $\begin{array}{c}\text { Nedenselliğin } \\
\text { Yönü }\end{array}$ & Test & $\begin{array}{c}\text { Test } \\
\text { Istatistiği }\end{array}$ & $\begin{array}{c}\text { Olasıl1k Değeri } \\
\text { (\%5) }\end{array}$ \\
\hline \multirow{2}{*}{$\Delta \mathrm{BO} \neq>\Delta \mathrm{ARGE}$} & $Z_{N, T}^{H N C}$ & 58.224 & 0.1179 \\
\cline { 2 - 4 } & $Z_{N}^{H N C}$ & 0.4085 & 0.5805 \\
\hline \multirow{3}{*}{$\Delta \mathrm{ARGE} \neq>\Delta \mathrm{BO}$} & $Z_{N, T}^{H N C}$ & 0.793 & 0.7769 \\
\cline { 2 - 4 } & $Z_{N}^{H N C}$ & -0.4627 & 0.4702 \\
\hline \multirow{2}{*}{$\Delta \mathrm{BO} \neq>\ln \mathrm{PAT}$} & $Z_{N, T}^{H N C}$ & 69.907 & $0.0900^{* * *}$ \\
\cline { 2 - 4 } & $Z_{N}^{H N C}$ & 0.6108 & 0.3207 \\
\hline \multirow{2}{*}{$\ln \mathrm{PAT} \neq>\Delta \mathrm{BO}$} & $Z_{N, T}^{H N C}$ & 18.796 & 0.5247 \\
\cline { 2 - 4 } & $Z_{N}^{H N C}$ & -0.2744 & 0.6869 \\
\hline
\end{tabular}

Not: *, ** ve *** sırasiyla $\% 1, \% 5$ ve $\% 10$ anlamlllık düzeyinde değișkenler arasında nedenselliğin olduğunu göstermektedir. $\neq>$ simgesi nedenselliğin yönünü göstermektedir. Test istatistikleri 789 yineleme ile elde edilmiştir.

Ekonomik büyüme, patent başvurusu ve ar-ge harcamalarının modellendiği çalışmada Dumitrescu-Hurlin nedensellik testi kullanılmış olup elde edilen bulguların sonuçları Tablo 7'de verilmiştir. Tablo 7 incelendiğinde sadece büyüme oranından patent başvurularına doğru tek yönlü ilişki görülmektedir. Diğer 


\section{İbrahim ÇÜTÇÜ \& Turgay BOZAN}

değişkenler arasında herhangi bir nedensellik ilişkisi tespit edilememiştir. Elde edilen sonuç hipotez ve literatür ile kısmen çelişmesine rağmen büyüme oranlarındaki değişimin patent başvurularını etkilediği sonucuna da ulaşılmaktadır. Ekonomik büyüme, ülke refahını arttıracağı için gerek kamu gerekse özel sektörün bu refahtan inovasyona pay ayıracağı düşünülmektedir.

\section{Sonuç}

Çalışma kapsamında G7 ülkelerinde (Dünya Bankası veri tabanında ilgili veriler bulunmadiğından İtalya hariç tutulmuştur) 1981-2016 dönemi için Ar-Ge harcamalarının milli gelire oranı ve patent sayıları ile ekonomik büyüme arasındaki karşılıklı ilişki araştırılmıştır. Yeniliğin göstergesi olarak kabul edilen Ar-Ge harcamaları ve patent başvuru sayıları ile ekonomik büyüme arasındaki ilișkinin analizinde G7 ülkeleri arasında yatay kesit bağımlılığı olduğu sonucuna ulaşılmıştır. Bu durum günümüz küresel dünyası ile de uyumlu olup G7 ülkelerinden birinde yaşanacak krizin, diğer ülkeleri de etkisi altına alacağını göstermektedir. $\mathrm{Bu}$ nedenle, gerek G7 ülkelerinin geleceğini kurgulayan yöneticiler gerekse de G7 ülkeleri, kendi politikalarını geliştirirken bu durumu dikkate alarak geleceğe yön vermesi gerektiği değerlendirilmektedir. Ayrıca eşbütünleşme testlerinden elde edilen sonuçlara bakıldığında, ekonomik büyüme ile inovasyon arasında orta ve uzun dönemli ilişki olduğu sonucuna ulaşılmıştır. Beklentiler dâhilinde çıkan bu sonuca göre inovatif gelişmeler ve yenilikçi politikaların orta ve uzun dönemde ekonomik büyümeyi etkilediği söylenebilir. Katsayı tahmincisinden de görüleceği üzere G7 ülkelerinin bu yönde uygulayacağı politikalar, gerek iç dengelerini gerekse de küresel ekonomik gelişmeyi pozitif yönde etkileyecektir. G7 ülkelerinin dünya milli gelirindeki payı da düşünüldüğünde bu ülkelerin alacağı her karar büyük önem arz etmektedir. Çünkü küresel dalgalanmalar tüm piyasaları çok hızlı bir şekilde etkilemektedir.

Literatür taraması kısmında verilen çalışma sonuçlarından da görüleceği üzere bu araştırma bulgusu, literatürde yer alan araştırma bulguları ile çelişmektedir. Örneğin, İnekwe (2015) tarafından gelişmekte olan ülkeler üzerinde yapılan çalışmada Ar-Ge harcamalarının ekonomik büyüme üzerinde pozitif etkisi olduğu sonucuna ulassılmıștır. Benzer şekilde, Altıner ve Toktaş (2017) tarafından 21 gelişmekte olan ülkenin 1992-2015 yılları arası verileri kullanılarak yapılan çalışma sonucunda yeniliğin ekonomik büyüme üzerinde pozitif etkisi olduğu sonucuna ulaşılmıştır. Çalışmada ise ar-ge harcamaları ile ekonomik büyüme arasında negatif ilişki olduğu sonucuna ulaşılmıştır. Bu durum farklı şekillerde yorumlanabilir. Bunların başında, seçilen ülke grubu, dünyanın en gelişmiş ülkelerini kapsadığı için Ar-Ge harcamaları zaten yüksek seviyede olduğudur. Diğer bir neden, Ar-Ge harcamaları ile ekonomik büyüme arasındaki negatif yönlü ilişkinin kriz dönemlerinde Ar-Ge harcamaları artırılsa dahi büyümenin diğer yıllara göre daha düşük olmasından kaynaklanabileceği şeklinde değerlendirilmektedir. Ayrıca Ar-Ge ile ekonomik büyüme arasındaki negatif ilişkinin nedeni olarak bazı ülkelerin Ar-Ge çıktılarını ürüne dönüştürme konusunda diğer ülkelere nazaran daha az etkin olmasından veya pazarlama kabiliyetlerinin diğer ülkelere nazaran daha yetersiz olmasından kaynaklanabileceği değerlendirilmektedir.

Araştırmada elde edilen diğer bulgu ise büyüme oranlarından patent başvurularına doğru tek yönlü nedensellik ilişkisinin olduğudur. Bu sonuç literatürde Adak (2015), Altıner ve Toktaş (2017), Türedi (2016), Sinha (2008), Josheski ve Koteski (2011) gibi birçok çalışmayı desteklemektedir. Elde edilen nedensellik ilişkisinin gerekçesi olarak; incelen ülkelerin dünyanın en büyük ekonomilerinden oluşması ve bu ülkelerin sürdürülebilir ekonomik büyümeyi 
sağlamak maksadıyla Ar-Ge'ye ilave olarak yenilik performansını etkileyen diğer hususlara ağırlık vermesinden kaynaklanabileceği değerlendirilmektedir. Ayrıca gelişmiş ülkelerin birçoğunda, gerek kamu (özellikle üniversiteler), gerekse özel sektör tarafından alınan patentlerin sayısını artırmaya yönelik teşvik mekanizmalarının yürürlüğe sokulduğu bilinmektedir. Mülkiyet Hakkı Yönetimi konusunda yöneticilerin bilgilendirilmesini de içeren bu politikalar firmaların patent yönetimini daha profesyonel şekilde gerçekleștirmesine neden olmaktadır.

Analizlerden elde edilen bulgulara göre; girişimcilik kültürünü artırmaya yönelik eğitim programları geliştirilmesi, girişimcilik kültürünü artırmaya yönelik eğitimler dışında ilave teşvik mekanizmalarının arttırılması, yenilik çabalarını desteklemeye yönelik etkin bir mülkiyet hakkı yönetim sistemi kurulması ve firma yöneticilerinin bu konudaki bilgi seviyelerini artırmaya yönelik eğitimler planlanması, katma değeri yüksek teknolojili ürünlerin geliştirilmesine yönelik teşvik politikalarının yürürlüğe konulması önerilmektedir. Ayrıca benzer çalışmaların farklı örneklemler üzerinden farklı dönemler ve analiz yöntemleri ile yapılmas1, ekonomik büyümeyi etkileyen girişimcilik, ekonomik kriz vb. diğer hususların da dikkate alındığı çalışmalar yapılması durumunda literatüre önemli katkılar sağlanacağı düşünülmektedir.

\section{Kaynakça}

Adak, M. (2015). Technological Progress, Innovation And Economic Growth; The Case Of Turkey. Procedia-Social and Behavioral Sciences, 195, 776-782.

Aghion, P. and Howitt, P. (1992). A Model Of Growth Through Creative Destruction. Econometrica, 60(2), 323-351.

Alene, A. D. (2010). Productivity growth and the effects of R\&D in African agriculture. Agricultural Economics, 41(3-4), 223-238.

Altiner, A. ve Y. Toktas (2017). The Effects of Innovation on Economic Growth in the Emerging Market Economics: Panel Data Analysis. Journal of Current Researches on Business and Economics, 7(2), 477-496.

Audretsch D.B., W. Bonte, M. Keilbach (2008). Entrepreneurship Capitalandits Impact on Knowledge Diffusion and Economic Performance. Journal of Business Venturing, 23, 687-698.

Ballı, E. ve G. Güreşçi (2017). İnovasyon ve Ekonomik Büyüme: Üst ve Üst-Orta Gelirli Ülkeler Örneği. Yönetim ve Ekonomi Araştırmaları Dergisi,15, 99-112.

Barro, R. J. (1991). Economic Growth In A Cross Section Of Countries. The Quarterly Journal of Economics, 106(2), 407-443.

Betz, F. (2003). Managing Technological Innovation: Competitive Advantage from Change. New Jersey: John Wiley \& Sons.

Breush, T. S. ve A. R. Pagan (1980). The Lagrange Multiplier Test and its Applications to Model Specification in Econometrics. The Review of Economic Studies, 47(1), 239-253.

Brouwer, M. T. (2000). Entrepreneurship and Uncertaintly: Innovation and Competition Among the Many. Small Business Economics, 15(2), 149-160.

Bujari, A. A., Martínez, F. V., and Lechuga, G. P. (2016). Impact Of Derivatives Markets On Economic Growth in Some Of The Major World Economies: A 
Difference-GMM Panel Data Estimation (2002-2014). Aestimatio: The IEB International Journal of Finance, (12), 110-127.

Cameron, G. (1996). Innovation and Growth: A Survey of the Empirical Evidence, 1-34. Oxford: Nuffield College.

Di Ioiro, F. and Fachin, S., (2008). A Note on the Estimation of Long-run Relationships in Dependent Cointegrated Panels. MPRA Paper, 12053, University Library of Munich, Germany.

Drucker, P. F. (1985). The Changed World Economy. Foreign Affairs, 64(4), 768791.

Dumitrescu, E. I. and C. Hurlin (2012). Testing For Granger Non-Causality in Heterogeneous Panels. Economic Modelling, 29, 1450-1460.

Eberhardt, M. ve Bond, S. (2009). Cross-Section Dependence in Nonstationary Panel Models: A Novel Estimator. MPRA Paper No. 17692, University Library of Munich, Germany.

Elçi, Ş. (2007). Inovasyon Kalkınmanın ve Rekabetin Anahtarı. Ankara: Nova Yayınları.

Genç, M. C., and Atasoy, Y. (2010). Ar\&Ge Harcamaları Ve Ekonomik Büyüme İlişkisi: Panel Veri Analizi. Bilgi Ekonomisi ve Yönetimi Dergisi, 5(2). 27-34.

Goel, R. K., Payne, J. E., and Ram, R. (2008). R\&D Expenditures And US Economic Growth: A Disaggregated Approach. Journal Of Policy Modelling, 30(2), 237250.

Galindo, M. and M.P. Mendez (2013). Innovation, Entrepreneurship and Economic Growth. Management Decision, 51 (3), 501-514.

Geroski, P., S. Machin and J. V. Reenen (1993). The Profitability of Innovating Firms. The Rand Journal of Economics, 24(2), 198-211.

Grossman, G. M., and H. Elhanan (1990). Trade, Innovation, and Growth. American Economic Association, 80(2), 2-3.

Grossman, G. M., and Helpman, E. (1991). Trade, Knowledge Spillovers, And Growth. European Economic Review, 35(2-3), 517-526.

Gülmez, A., ve A. G. Akpolat (2014). Ar-Ge \& İnovasyon Ve Ekonomik Büyüme: Türkiye Ve AB Örneği İçin Dinamik Panel Veri Analizi. AİBÜ Sosyal Bilimler Enstitüsü Dergisi, 14(2), 1-17.

Güloglu, B. ve Tekin, R. B. (2012). A Panel Causality Analysis Of The Relationship Among Research And Development, Innovation and Economic Growth in High-Income OECD Countries. Eurasian Economic Review, 2(1), 32-47.

Hasan, I., and C. L. Tucci (2010). The Innovation Economic Growth Nexus: Global Evidence. Research Policy, 39(10), 1264-1276.

Issık, N. ve E.C. Kılınç (2011). Bölgesel Kalkınmada Ar-Ge Ve İnovasyonun Önemi: Karşılaştırılmalı Bir Analiz. Osmangazi Üniversitesi İ̈BF Dergisi, 6 (2), 9-54.

Josheski, D. and Koteski, C. (2011). The Causal Relationship Between Patent Growth and Growth of GDP With Quarterly Data in The G7 Countries: Cointegration, ARDL And Error Correction Models. MPRA Paper, 33153, University Library of Munich, Germany. 
Kantarc1, T. (2017). Ar-Ge ve Yeniliğin Gelissmekte Olan Ülkeler Bağlaminda Makroekonomik Performans Üzerine Etkisi. (Yayınlanmamış Yüksek Lisans Tezi). Namık Kemal Üniversitesi Sosyal Bilimler Enstitüsü, Ankara.

Karaöz, M., M. Albeni (2004). Türkiye'de Teknoloji Cabalarına İlisskin Bir Değerlendirme: Türkiye'de Patent Aktivitesi. III. Bilgi Teknolojileri Kongresi, Bilgitek, Pamukkale Üniversitesi, Denizli.

Kavak, Ç. (2009). Bilgi Ekonomisinde İnovasyon Kavramı ve Temel Göstergeleri. Akademik Bilişim Konferansı Bildirileri, Şanlıurfa.

Keith, E.L. and G.J. Theodore (1984). Characterization of Innovations Introduced on the U.S: Market in 1982, The Futures Group, U.S.

Lichtenberg, F. R. (1992). R\&D Investment and International Productivity Differences. NBER Working Paper No.4161.

Luecke R. (2011). Managing Creativity and Innovation, İş Dünyasinda Yenilik ve Yaratıcılık. Parlak, T. (Çev.). İstanbul: İs Bankası Yayınları.

OECD (2007). Growth: Rationale For An Innovation Strategy, Statistical Office of the European Communities, Luxembourg.

OECD. (2018). World Development Indicators. Erişim Adresi: https://data.oecd.org/rd/gross-domestic-spending-on-r-d.htm

Örtlek, Z. (2015). İnovasyon ve Bölgesel Kalkınma Perspektifinden Türkiye. (Yayınlanmamış Yüksek Lisans Tezi ). Aksaray Üniversitesi Sosyal Bilimler Enstitüsü, Aksaray.

Özcan, B., ve A. Ar1 (2014). Araștırma-Geliștirme Harcamaları ve Ekonomik Büyüme İlişkisi: Panel Veri Analizi. Maliye Dergisi, 166(1), 39-55.

Özer, M., ve Çiftçi, N. (2009). Ar-Ge Harcamaları Ve İhracat İlişkisi: OECD Ülkeleri Panel Veri Analizi. Dumlupinar Üniversitesi Sosyal Bilimler Dergisi, 23(3), 3950 .

Özkul, G. ve E. Örün (2016). Girişimcilik ve İnovasyonun Ekonomik Büyüme Üzerindeki Etkisi: Ampirik Bir Araştırma. Girişimcilik ve İnovasyon Yönetimi Dergisi, 5(2), 17-51.

Pece, A. M., Simona, O. E. O. and Salisteanu, F. (2015). Innovation And Economic Growth: An Empirical Analysis For CEE Countries. Procedia Economics and Finance, 26, 461-467.

Pesaran, M. H. (2004). General Diagnostic Tests for Cross Section Dependence in Panels. CWPE 0435.

Pesaran, M. H. (2007). A Simple Panel Unit Root Test in the Presence of Crosssection Dependence. Journal of Applied Economics, 22(2), 265-312.

Pesaran, M. H. and T. Yamagata. (2008). Testing Slope Homogeneity in Large Panels. Journal of Econometrics, 142, 50-93.

Pesaran, M. H., A. Ullah and T. Yamagata. (2008). A Bias-Adjusted LM Test of Error Cross-Section Independence. Econometrics Journal, 11, 105-127.

Romer, P. M. (1986). Increasing Returns and Long-Run Growth. Journal of Political Economy, 94(5), 1002-1037. 
Shiller, R. J. (2012). The Subprime Solution: How Today's Global Financial Crisis Happened, And What To Do About It. Princeton University Press.

Sinha, D. (2007). Patents, Innovations And Economic Growth in Japan and South Korea: Evidence From Individual Country and Panel Data. MPRA Paper, 2547, University Library of Munich, Germany.

Sylwester, K. (2001). R\&D And Economic Growth. Knowledge, Technology \& Policy, 13(4), 71-84.

Tushman, M. and D. Nadler (1986). Organizing for Innovation. California Management Review, 18(3), 74-92.

Türedi, S. (2016). The Relationship between R\&D Expenditures, Patent Applications and Growth: A Dynamic Panel Causality Analysis for OECD Countries. Anadolu Üniversitesi Sosyal Bilimler Dergisi, 16, 39-48.

Ülkü, H. (2004). R\&D, Innovation, and Economic Growth: An Empirical Analysis. IMF Working Paper WP/04/85. Erişim Adresi: https://www.imf.org /external/pubs/ft/wp/2004/wp04185.pdf

Yılmaz, Z., ve E. İncekaș (2018). Türkiye'de İnovasyon Ve Bölgesel Kalkınma. Kırklareli Üniversitesi Sosyal Bilimler Dergisi, 2(1), 154-169.

Wang, C. (2013). The Long-run Effect of Innovation on Economic Growth. Erissim Adresi: https://www.murdoch.edu.au/School-of-Business-andGovernance /_ document/Australian-Conference-of-Economists/The-longrun-effect-of-innovation-on-economic-growth.pdf

Westerlund, J. (2008). Panel Cointegration Tests of the Fisher Effect. Journal of Applied Economietrics, 23(2), 193-223.

Yanyun, Z., Mingqian, Z. (2004). R\&D and Economic Growth-Panel Data Analysis in ASEAN+3 Countries. Seoul Conference 2004, Korea and the World Economy III.

Zhang, L., W. Song, ve J. He (2012). Empirical Research on the Relationship between Scientific Innovation and Economic Growth in Beijing. Technology and Investment, 3(3), 168-173. 